\title{
Proceeding
}

Supplementary Issue: Spring Conferences of Sports Science. Costa Blanca Sports Science Week, 26-28 April 2018. Calpe.

Alicante, Spain

\section{Emotional intelligence in university Physical Education teachers}

\author{
PILAR PUERTAS-MOLERO $\triangle$, ANTONIO PÉREZ-CORTÉS, MARÍA SÁNCHEZ-ZAFRA, CAROLINA \\ CASTAÑEDA-VÁZQUEZ \\ University of Granada, Spain
}

\begin{abstract}
Currently, teaching is one of the professions most highly affected by stress due to the large number of tasks involved and the continuous contact with students, among others, which generate weariness towards the profession, hence the importance of developing high levels of Emotional Intelligence. Why this is so important is that it enables teachers to deal optimally with frustration, and to know how to act appropriately when facing the various situations that arise in a classroom, as well as giving them the ability to communicate and listen, and thus adapt themselves to those situations. These factors are necessary to ensure the promotion of a correct teaching-learning process. By means of this research we aim to discover the mental state of university teachers by conducting a cross-sectional and descriptive study. As a data collection instrument, the TMMS24 was applied to a sample of Physical Education teachers working in universities. The results showed that people who teach this subject have good levels of empathy with their students, possessing the ability to understand and empathise with them, thus having a good ability to control their feelings, and thus enhancing their mental well-being, which is reflected in the teacher's job satisfaction. Key words: EMOTIONAL INTELLIGENCE, TEACHERS, UNIVERSITY, MENTAL WELLNESS, PHYSICAL EDUCATION.
\end{abstract}

\section{Cite this article as:}

Puertas-Molero, P., Pérez-Cortés, A., Sánchez-Zafra, M., \& Castañeda-Vázquez, C. (2018). Emotional intelligence in university Physical Education teachers. Journal of Human Sport and Exercise, 13(2proc), S505-S513. doi:https://doi.org/10.14198/ihse.2018.13.Proc2.34

\footnotetext{
Corresponding author. Department of Didactics of Musical, Plastic and Body Expression, University of Granada, Spain. E-mail: pilarpuertasmolero@gmail.com

Supplementary Issue: Spring Conferences of Sports Science. Costa Blanca Sports Science Week, 26-28 April 2018. Calpe. Alicante, Spain.

JOURNAL OF HUMAN SPORT \& EXERCISE ISSN 1988-5202

(C) Faculty of Education. University of Alicante

doi: 10.14198/jhse.2018.13.Proc2.34
} 


\section{INTRODUCTION}

The teaching profession through the various stages of education is dependent on a great many skills that teachers have to acquire and subsequently transmit (Reisoglu, Gedik \& Goktas, 2013). From this perspective, the teacher's task is to focus on creating situations that will facilitate the students' success and integral development, transferring up-to-date and motivating knowledge and contributing to students' development during the teaching-learning process of an autonomy that will help them cope with real life situations in the future (Asrar-ul-Haq, Anwar \& Hassan, 2017; Gutiérrez, Ibáñez, Aguilar \& Vidal, 2016).

However, the significant numbers of abilities these professionals have to master, their continuous contact with students and colleagues, difficult situations they have to face on a daily basis and extra work that has to be done outside working hours, among others, are some of the challenges that expose teachers to high levels of pressure (Barłożek, 2015). These factors are generating symptoms of stress and anxiety in teachers, leading to such consequences as feelings of emptiness, low job satisfaction, low self-esteem, insomnia, eating disorders and even the development of "burnout", which has severe repercussions for the quality of teaching (Baranovska \& Doktorova, 2014; Pu, Hou, Ma \& Sang, 2017).

In this regard, authors such as Fernández-Berrocal, Cabello, Castillo \& Extremadura (2012), Goleman (2012) and Meshkat \& Nejati (2017), demonstrate that Emotional Intelligence is a psychosocial factor, contributing positively to the handling of tense situations, which is understood as an ability to perceive, assimilate, understand and manage emotions. Likewise, this construct acts by making good use of a person's ability to manage both their own emotions and those of others, allowing them to discriminate between the positive and negative effects of emotions, and facilitating the adjustment and control of thoughts and actions (Joseph \& Newman, 2010; Patel, 2017).

Similarly, research studies such as the one by Pyhältö, Pietarinen \& Salmela (2011), emphasise the need to develop positive emotions in teaching staff, since they are a crucial factor in the teaching-learning process, the understanding of feelings in educational contexts is thus an indispensable component in the training of teachers. In addition, Hosotani \& Imai (2011), along the same lines, highlighted the fact that within teachers' work environment there is a wide range of factors that influence their emotions, among them those perceived between teacher and student, teacher and colleagues, teachers and superiors and so on (Salguero, Extremera, \& Fernández-Berrocal,2012).

For these reasons, several research studies have already been carried out that bring to light the fact that one of the most useful methods of developing Emotional Intelligence is the practice of physical and sporting activity, which reinforces emotional skills through the feeling of belonging to a group, thus improving the ability to cooperate in order to achieve a common goal (Kim, Khon \& Aidosova, 2016; Tillmann, Krishnadas, Cavanagh \& Petrides, 2013).

Among the many benefits that the practice of physical and sporting activity can bring to university teachers, at an emotional level we can highlight the acquisition of competitive attitudes, as well as an appreciation of the value of the activity and the effort invested in it, in such a way as to orient teachers towards the achievement of goals (Adilogullari \& Senel, 2014). At the physical level, a positive predisposition is developed towards understanding physical exercise as a valuable means in order to improve mental health as much as physical condition, generating an adherence to healthy habits (Duran, Lavega, Salas, Tamarit \& Invernó, 2015). At the social level, an increase in both interpersonal and intrapersonal skills is produced, facilitating social relationships as a result of the multiple interactions (Gil \& Martínez, 2015). And at a rational level, an 
understanding is developed that enables to adapt to the different features of each activity in order to perform it optimally (Ristea, Macovei \& Leonte, 2016).

According to the aforementioned, the teaching profession is in an alarming situation However, the regular practice of physical and sporting activity, provides adequate levels of Emotional Intelligence, the benefits of which can then be extrapolated to any daily activity; therefore this research study aims to describe levels of Emotional Intelligence and of physical activity in university PE teachers and to establish the relationship between emotional intelligence, the practice of physical activity and the gender of the participants.

\section{MATERIAL AND METHOD}

\section{Design and participants}

A non-experimental ex post-facto study was carried out, descriptive and cross-sectional, with a single measurement. The sample was made up of 437 university teachers aged between 24 and 70 ( $M=44.30$; D.T. $=10.057)$, representing $49.9 \%$ men $(n=218)$ and $50.1 \%$ women ( $n=219)$. In order to decide on the study sample, we considered teachers working in the areas of corporal expression and physical and sporting education. Regarding the studied population, a representative sample was established by stratified random sampling techniques with a sampling error of 0.05 and I.C. $=95.5 \%$.

\section{Variables}

The following variables were used in this study:

- Gender: categorised as male and female.

- Age: the age of each teacher taking part in the study was established.

- Physical activity: whether or not they practise physical activity for three hours or more per week.

- Emotional Intelligence: establishing the participants' average score with regard to emotions and feelings, using a scale of 1 to 5 points in order to gauge emotional intelligence and the levels of attention to feelings, clarity of feelings and mood repair.

\section{Instruments}

In carrying out this research study the following instruments were used:

- Ad-Hoc questionnaire. A questionnaire was developed specifically to register sociodemographic variables and the practice or not of physical activity.

- Trait Meta-Mood Scale-24 (TMMS-24) self-report scale. The original version of this instrument is the Trait Meta-Mood Scale (TMMS-48) created by Salovey, Mayer, Goldman, Turvey \& Palfai (1995), which assesses meta-knowledge of emotional states. TMMS-24 is the abridged version adapted to Spanish by Fernández-Berrocal, Extremera and Ramos (2004). The questionnaire is made up of 24 items, which are graded by means of a Likert scale with five options, ranging from 1: totally disagree to 5: totally agree. The items are structured in three emotional intelligence key dimensions with 8 items for each of them: attention to feelings (items 1-8; e.g., "I pay attention to feelings"), clarity of feelings (items 9-16; e.g., "I can often define my feelings") and mood repair (items 17-24; e.g., "Although I sometimes feel sad, I am often optimistic"). Reliability of the original study for each component is: attention ( $\alpha=0.900)$, clarity $(\alpha=0.900)$ and repair $(\alpha=0.860)$. In the present study the reliability of the whole scale was $\alpha=0.889$, in attention to feelings $\alpha=0.909$, clarity of feelings $\alpha=$ 0.915 and mood repair $\alpha=0.886$, which is quite acceptable. 


\section{Procedure}

In order to request the collaboration of participants, all of whom were university teachers in an area related to corporal expression and physical education and sport, an explanatory letter was written by the Department of Didactics of Music, Plastic and Corporal Expression of the University of Granada, giving details about the aim and nature of the research stud which was sent out by e-mail. The collection of data was carried out after school hours without any problems, the research team being constantly available to ensure correct application of the instruments described and to answer any queries. It should be noted that the 437 participants' right to confidentiality was observed and 43 questionnaires were invalidated because they were not properly completed.

\section{Data analysis}

Statistical analysis of the data was performed using the statistical software IBM SPSS $尺$ in its version 22.0 for Windows. For basic descriptors, means and frequencies were used, whereas for the study of relations between variables t-student was used for dichotomous factors. Internal reliability of the instrument used was assessed by means of Cronbach's Alpha, which had a reliability index of $95.5 \%$.

\section{RESULTS}

Table 1 shows basic descriptors relating to gender of participants, practice of physical activity, and emotional intelligence of the university teachers. Women make up $50.1 \%$ of the sample of study, while men represent $49.9 \%$. Regarding the practice of physical activity, $59.7 \%$ of the subjects practised at least three hours a week and $40.3 \%$ did not. Regarding feelings and emotions, general emotional intelligence presents acceptable average values ( $M=3.70 ;$ S.D. $=0.544)$; the dimension with the lowest mean is attention to feelings $(M=28.23$; S.D. $=6.901)$, followed by clarity of feelings $(M=30.04$; S.D. $=5.999)$ and mood repair $(\mathrm{M}=30.52 ; \mathrm{S} . \mathrm{D} .=6.077)$.

Table 1. Basic descriptors regarding gender, practice of physical activity and levels of Emotional Intelligence in university teachers

\begin{tabular}{|c|c|c|c|c|}
\hline \multicolumn{3}{|c|}{ Gender } & \multicolumn{2}{|c|}{ PPA } \\
\hline Male & & & & $59.7 \%$ \\
\hline Female & & & & $40.3 \%$ \\
\hline Category & Min & Max & Mean (M) & S.D. \\
\hline GEI & 1.00 & 5.00 & 3.70 & 0.544 \\
\hline $\mathrm{AF}$ & 8.00 & 40.00 & 28.23 & 6.901 \\
\hline CF & 8.00 & 40.00 & 30.04 & 5.999 \\
\hline MR & 8.00 & 40.00 & 30.52 & 6.077 \\
\hline
\end{tabular}

${ }^{*}$ Practice of Physical Activity (PPA) * General Emotional Intelligence (GEI) * Attention to Feelings (AF) * Clarity of Feelings (CF) * Mood Repair (MR)

Analysis of the university teacher's emotional intelligence by gender (Table 2 ) showed significant associations both in general emotional intelligence $\left(p=0.26^{*}\right)$ and in the dimension attention to feelings $(p=$ $\left.0.002^{*}\right)$. Women $(M=3.75$; S.D. $=0.503)$ demonstrated higher parameters in emotional intelligence than men 
$(M=3.64 ;$ S.D. $=0.571)$, as was also the case in attention to feelings, with women registering $M=29.27$ (S.D.= 6.80 ) and $\mathrm{men} M=27.19$ (S.D.=27.19).

Table 2. Emotional Intelligence by gender in university teachers

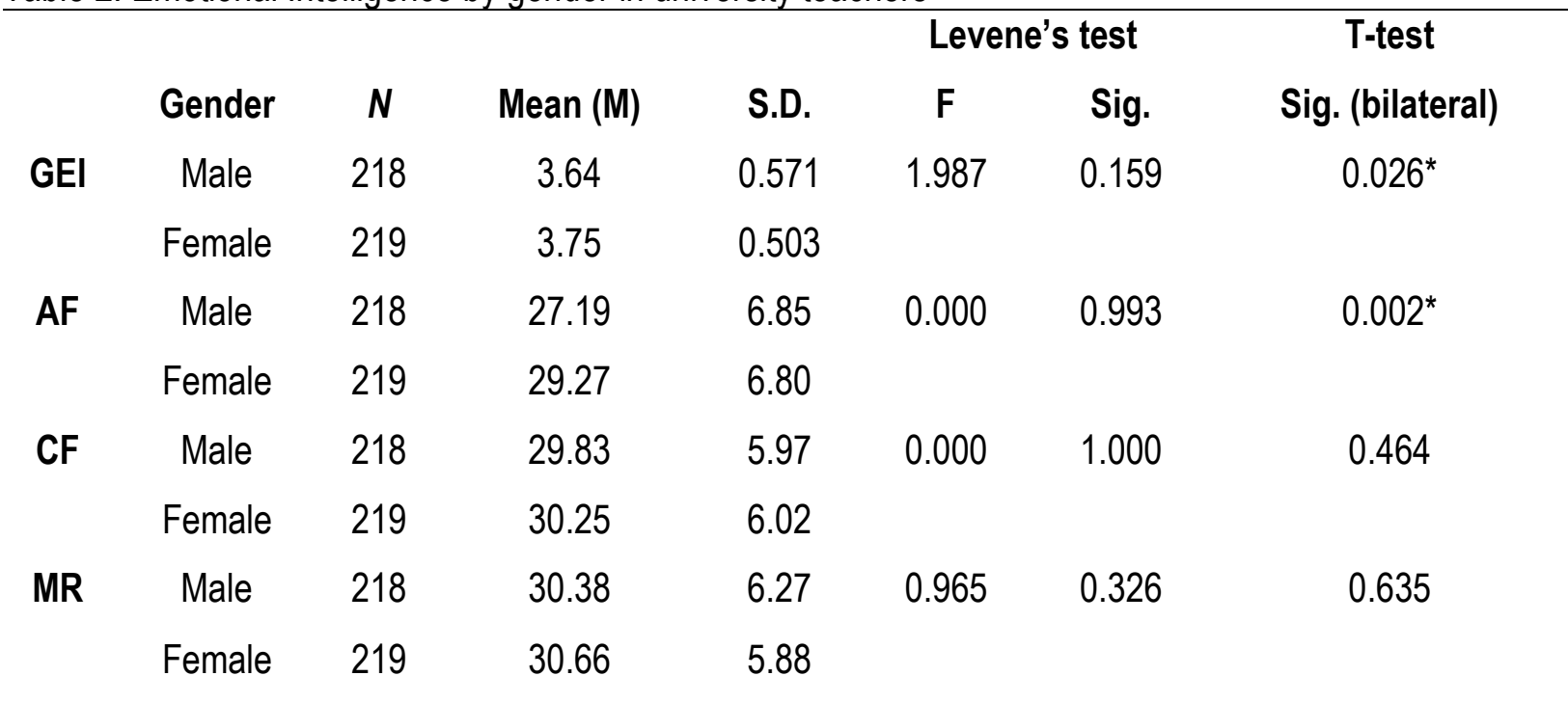

${ }^{*}$ General Emotional Intelligence (GEI) * Attention to Feelings (AF) ${ }^{*}$ Clarity of Feelings (CF) * Mood Repair (MR)

The study of emotional intelligence in relation to the practice or not of physical activity (Table 3) brought statistically significant differences for general emotional intelligence $\left(p=0.001^{*}\right)$, and for the dimension clarity of feelings $\left(p=0.018^{*}\right)$ and mood repair $\left(p=0.004^{*}\right)$. University teachers who practise physical activity for three or more hours a week have greater emotional intelligence $(M=3.76$; S.D. $=0.540)$ than those who do not follow this pattern $(M=3.59$; S.D. $=0.532)$. Regarding clarity of feelings, those who practise physical activity have higher values $(M=30.60$; S.D. $=5.815)$ than those who do not $(M=29.22$; $S . D .=6.185)$, the same applying to mood repair $(M=31.21$; S.D. $=6.145$ and $M=29.51$; S.D. $=5.845)$.

Table 3. Emotional intelligence by practice of physical activity in university teachers.

\begin{tabular}{|c|c|c|c|c|c|c|c|}
\hline & \multirow[b]{2}{*}{$\mathrm{PPA}^{*}$} & \multirow[b]{2}{*}{$N$} & \multirow[b]{2}{*}{ Mean (M) } & \multirow[b]{2}{*}{ S.D. } & \multicolumn{2}{|c|}{ Levene's test } & \multirow{2}{*}{$\begin{array}{c}\text { T-test } \\
\text { Sig. (bilateral) }\end{array}$} \\
\hline & & & & & $F$ & Sig. & \\
\hline \multirow[t]{2}{*}{ GEI } & Yes & 261 & 3.76 & 0.540 & 0.022 & 0.882 & $0.001^{*}$ \\
\hline & No & 176 & 3.59 & 0.532 & & & \\
\hline \multirow[t]{2}{*}{$\mathrm{AF}$} & Yes & 261 & 28.64 & 6.878 & 0.006 & 0.939 & 0.132 \\
\hline & No & 176 & 27.63 & 6.910 & & & \\
\hline \multirow[t]{2}{*}{ CF } & Yes & 261 & 30.60 & 5.815 & 1.106 & 0.294 & $0.018^{*}$ \\
\hline & No & 176 & 29.22 & 6.185 & & & \\
\hline \multirow[t]{2}{*}{ MR } & Yes & 261 & 31.21 & 6.145 & 0.055 & 0.815 & $0.004^{*}$ \\
\hline & No & 176 & 29.51 & 5.845 & & & \\
\hline
\end{tabular}




\section{DISCUSSION}

The aim of this research has been to discover the levels of emotional intelligence in university teachers who teach in a field related to corporal expression or physical and sporting activity, as well as the relationship between this variable and the level of physical activity according to gender, there being several authors who confirm that this construct, together with physical exercise, plays a vital role in the area of education, as well as in that of social and mental wellbeing (Barłożek, 2015; Cazalla \& Moreno, 2016; Di Fabio \& Kenni, 2011; Munsawaengsub, Yimklib, Nanthamongkolchai \& Apinanthavech, 2009; Yildizbas, 2017).

The present study, involving 437 university teachers, revealed that the levels of Emotional Intelligence in these educational professionals are acceptable, the data being similar to those presented by Aguayo-Muela and Aguilar-Luzon (2017), who carried out a review of 16 studies conducted with Spanish teachers as the participants, finding this construct optimal. Likewise, Yildizbas (2017), established that teachers in Turkey who taught students at different educational stages, had suitable levels of Emotional Intelligence, concurring with this study on the dimension with the highest score being mood repair (Mouton, Hansenne, Delcour \& Cloes, 2013; Tsvetkova, 2017).

With regard to levels of Emotional Intelligence by gender, in this study the highest scores were found in females both at the general level and in each of the dimensions. Similarly, the study conducted by MeridaLópez, Extremera \& Rey (2017) on a sample of 310 teachers in different educational stages, concluded that women show higher levels in relation to the studied variable, which acted as a means of protection against feelings of depression or anxiety, the data being similar to those found by Chan (2008).

Likewise, Mounton, Hansnne, Delecour, Cloes (2013) and Yin (2015), confirmed that females in general tended to show higher levels of Emotional Intelligence, however, in their studies on a population of university teachers they found that men's levels were higher in intrasocial abilities while women excelled in intersocial skills as a means to face effectively situations in which they were under pressure.

In the same way, the research study conducted by Alghamdi, Aslam \& Khan (2017), involving 100 university teachers in Saudi Arabia, revealed no differences in Emotional Intelligence between genders, a discovery also supported by the study "Relationship between Job Satisfaction and Emotional Intelligence among school teachers of Kangra District of Himachal Pradesh", conducted by Shinu, Renu and Lalita (2016).

In terms of relations between Emotional Intelligence and the practice of physical and sporting activity in university teachers, significant data were obtained relating to those teachers who practised physical exercise for Emotional Intelligence generally and in the dimensions of clarity of feelings and mood repair. These data were supported by other studies such as those by Albo, Núñez \& León (2010), Szabo \& Urbán (2014) and Fernández, Almagro \& Sáenz (2014), who highlight that teachers who practise more physical activity are able to develop positive feelings and redirect their frustrations, thus being able to act in the best way when facing stressful situations (Extremera \& Fernández-Berrocal, 2012; Salovey, Stroud, Woolery \& Epel, 2002; Sloan, 2014).

In this regard, authors such as Adilogullari \& Senel (2014), Gil \& Martínez (2015) and Ristea, Macovei \& Leonte (2016) confirmed that those teachers who practised physical and sporting activity in their free time had higher levels of Emotional Intelligence and set a good example to their students, instilling principles into them, and showing them how to channel frustrations and how to take decisions under pressure. 


\section{CONCLUSION}

Through this research study it has been demonstrated that half the university teachers who teach in an area related to Physical Education practise physical and sporting activities outside the working environment, in addition to having adequate levels of emotional intelligence, which demonstrates that the practice of exercise is connected with an increase in this psychosocial construct. It was likewise verified that emotional skills are stronger in women than in men.

With regard to the relationship between practice of physical activity and sport and Emotional Intelligence, it is apparent that physical exercise contributes positively to the increase of this construct, since those university teachers who practised sport outside the working environment had better emotional clarity and mood repair, and were thus able to face their working day satisfactorily.

Nevertheless, it has to be pointed out that a measure of the limitations of this study is the fact that although the population was significant, it is not possible to apply the results to the whole population since they only provide information on the population that was the object of the study. Additionally, what stands out from these results is the great value of the practice of physical activity in guaranteeing the mental wellbeing of these professionals, on whom depends the quality of the teaching-learning process. To be encouraged, therefore, are implementations that apply this psychosocial construct to university teachers, since they are in charge of the training and imparting knowledge to the professionals of the future.

\section{REFERENCES}

Adilogullari, I., y Şenel, E. (2014). Examination of the relationship between general self-efficacy beliefs, emotional intelligence levels and emotional self-efficacy levels of students in school of physical $\begin{array}{llll}\text { education and } \quad \text { sport. } & \text { 8nthropologist, }\end{array}$ https://doi.org/10.1080/09720073.2014.11891621

Aguayo-Muela, A. D., y Aguilar-Luzon, M. C. (2017). Main research results on emotional intelligence in Spanish teachers. Reidrocrea-Revista Electrónica de Investigación y Docencia Creativa, 6,170-193.

Albo, J., Núñez, J. L., y León, J. (2010). Analysis of the psychometric properties of the Spanish version of the Trait Meta-Mood Scale in a sports context. Psychological reports, 106(2), 477-489. https://doi.org/10.2466/pr0.106.2.477-489

Alghamdi, N. G., Aslam, M., y Khan, K. (2017). Personality Traits as Predictor of Emotional Intelligence among the University Teachers as Advisors. Education Research International, 17, 1-6. https://doi.org/10.1155/2017/9282565

Asrar-ul-Haq, M., Anwar, S., y Hassan, M. (2017). Impact of emotional intelligence on teacher's performance in higher education institutions of Pakistan. Future Business journal, 3(2), 87-97. https://doi.org/10.1016/j.fbj.2017.05.003

Baranovska, A., y Doktorova, P. D. (2014). The need to create a cognitive structure for primary and secondary school teachers in relation to the degree of burnout and emotional intelligence. Psychology and Psychiatry, 1, 491-498. https://doi.org/10.5593/sgemsocial2014/B11/S1.064

Barłożek, N. (2015). The Ecosystem of the Foreign Language Learner. Berlín, Alemania: Springer.

Cazalla, N., y Molero, D. (2016). Perceived emotional intelligence, dispositional optimism-pessimism, life satisfaction and teachers' personality in their initial training. RIE-Revista de Investigación Educativa, 34(1), 241-258. https://doi.org/10.6018/rie.34.1.220701 
Chan, D. (2008). Emotional intelligence, self-efficacy, and coping among Chinese prospective and inservice teachers in Hong Kong. Educational Psychology, 28(4), 397-408. https://doi.org/10.1080/01443410701668372

Di Fabio, A., y Kenny, M. (2011). Promoting emotional intelligence and career decisión making among Italian high school students. Journal Career Assess. 19, 21-34. https://doi.org/10.1177/1069072710382530

Durán, C., Lavega, P., Salas, C., Tamarit, M., e Invernó, J. (2015). Educación Física Emocional en Adolescentes. Identificación de Variables Predictivas de la Vivencia. Cultura, Ciencia y Deporte, 10(28), 5-18. https://doi.org/10.12800/ccd.v10i28.511

Extremera, N., y Fernández-Berrocal, P. (2012) Emotional intelligence as predictor of mental, social, and physical health. The Spanish Journal of Psychology, 91, 47-59.

Fernández, E. J., Almagro, B., y Sáenz, P. (2014). Explanatory model of psychological well-being in the university athletic context. Procedia-Social and Behavioral Sciences, 132, 255-261. https://doi.org/10.1016/j.sbspro.2014.04.307

Fernández-Berocal, P., Extremera N., y Ramos, N. (2004). Validity and reliability of the spanish modified version of the Trait Meta-Mood Scale. Psychological Reports, 94, 751-755. https://doi.org/10.2466/pro.94.3.751-755

Fernández-Berrocal, P., Cabello, R., Castillo, R., y Extremera, N. (2012). Gender differences in emotional intelligence: The mediating effect of age. Behavioral Psychology, 20(1), 77-89.

Gil, P., y Martínez, M. (2015). Emociones auto-percibidas en las clases de educación física en primaria. Universitas Psychologica, 14(3), 923-935. https://doi.org/10.11144/Javeriana.upsy14-3.eapc

Goleman, D. (2012). Inteligencia emocional. Barcelona: Editorial Kairós.

Gutiérrez, M., Ibáñez, R., Aguilar, R., y Vidal, A. (2016). Assessment of emotional intelligence in a sample of prospective Secondary Education Teachers. Journal of Education for Teaching, 42(2), 123-134. https://doi.org/10.1080/02607476.2016.1143144

Hosotani, R., y Imai K. (2011). Emotional experience, expression, and regulation of high-quality Japanese elementary school teachers. Teaching and Teacher Education, 27(6), 1039-1048. https://doi.org/10.1016/j.tate.2011.03.010

Joseph, D. L., y Newman, D. A. (2010). Emotional intelligence: An integrative meta-analysis and cascading model. Journal of Applied Psychology, 95(1), 54-78. https://doi.org/10.1037/a0017286

Kim, A., Khon, N., y Aidosova, Z. (2016). Emotional intelligence of a coach as a factor of coach-student interaction. Procedia-Social and Behavioral Sciences, 236, 265-270. https://doi.org/10.1016/j.sbspro.2016.12.026

Merida-López, S., Extremera, N., y Rey, L (2017). Looking psychological adjustment through emotional intelligence: Does teacher gender make a difference? Behavioral psychology, 25(3), 581-597.

Meshkat, M., y Nejati, R. (2017). Does Emotional Intelligence dependo on gender? A study on undergraduate english majors of three Iranian universities. Saga open, 7(3), 1-8. https://doi.org/10.1177/2158244017725796

Mouton, A., Hansenne, M., Delcour, R., y Cloes, M. (2013). Emotional intelligence and self-efficacy among physical education teachers. Journal of Teaching in Physical Education, 32(4), 342-354. https://doi.org/10.1123/itpe.32.4.342

Munsawaengsub, M., Yimklib, M., Nanthamongkolchai, P., y Apinanthavech, M. (2009). Effect of promoting self-esteem by participatory learning process on emotional intelligence among early adolescents. Journal of the Medical Association of Thailand, 92(7), 13-20.

Patel, S. K. (2017). Emotional intelligence of college level students in relation to their gender. The International Journal of Indian Psychology, 4(2), 2349-3429. 
Pu, J., Hou, H. P., Ma, R. Y., y Sang, J. Y. (2017). The effect of psychological capital between workfamily conflicto and job burnout in Chinese university teachers: Testing for mediation and moderation. Journal of Health Psychology, 22(14), 1799-1807. https://doi.org/10.1177/1359105316636950

Pyhältö, K., Pietarinen, J., y Salmela, K. (2011). Teacher-working-environment fit as a framework for burnout experienced by Finnish teachers. Teaching and Teacher Education, 27(7), 1101-1110. https://doi.org/10.1016/j.tate.2011.05.006

Reisoglu, I., Gedik, N., y Goktas, Y. (2013). Relationship between Pre-Service Teachers' Levels of SelfEsteem, Emotional Intelligence and Problematic Internet Use. Egitim ve bilim-education and science, 38(170), 150-165.

Ristea, C., Macovei, S., y Leonte, N. (2016). The Influence of Motor Activities on the Development of Emotional Intelligence. The European Proceedings of social and behavioural sciences, 11,379-384. https://doi.org/10.15405/epsbs.2016.06.52

Salguero, J. M., Extremera, N., y Fernández-Berrocal, P. (2012). Emotional intelligence and depression: The moderator role of gender. Personality and Individual Differences, 53(1), 29-32. https://doi.org/10.1016/i.paid.2012.02.006

Salovey, P., Mayer, J.D., Goldman, S.L., Turvey, C., y Palfai, T. P. (1995). Emotional attention, clarity, and repair: Exploring emotional intelligence using the Trait Meta-Mood Scale. En J. W. Pennebaker (Ed), Emotion, Disclosure, \& Health. (p. 125-151). Washington: American Psychological Association. https://doi.org/10.1037/10182-006

Salovey, P., Stroud, L., Woolery, A., y Epel, E. (2002) Perceived emotional in-telligence, stress reactivity, and symptom reports: further explorations using the Trait Meta-Mood Scale. Psychology and Health, 17, 611-627. https://doi.org/10.1080/08870440290025812

Shinu, H., Renu, B., y Lalita, K. (2016). Relationship between Job Satisfaction and Emotional Intelligence among school teachers of Kangra District of Himachal Pradesh. Pacific Business Review International, 8(11), 9-13.

Sloan, M. (2014). The consequences of emotional labor for public sector workers and the mitigating role of self-efficacy. The merican Review of Public Administration, 44(3), 274290. https://doi.org/10.1177/0275074012462864

Szabo, A., y Urbán, F. (2014). Do combat sports develop emotional intelligence? Kinesiology, 46 (1), 5360. Doi: 796.853.23:796.83:159.9.952

Tillmann, T., Krishnadas, R., Cavanagh, J., y Petrides, K. (2013). Possible rheumatoid arthritis subtypes in terms of rheumatoid factor, depression, diagnostic delay and emotional expression: An exploratory case-control study. Arthritis Research and Therapy, 15(2), 1-11. https://doi.org/10.1186/ar4204

Tsvetkova, H. (2017). Emotional intelligence as a mental basis of university teachers' professional selfdevelopment. Science and education, 8,49-59. https://doi.org/10.24195/2414-4665-2017-8-7

Yildizbas, F. (2017). The Relationship between Teacher Candidates' Emotional Intelligence Level, Leadership Styles and Their Academic Success. Eurasian Journal of Educational Research, 67, 215231. https://doi.org/10.14689/ejer.2017.67.13

Yin, H. (2015). The effect of teachers'emotional labour on teaching satisfaction: moderation of emotional $\begin{array}{llll}\text { intelligence. Teachers } \quad \text { and } & \text { 789-810. }\end{array}$ https://doi.org/10.1080/13540602.2014.995482

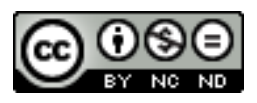

This title is licensed under a Creative Commons Attribution-NonCommercial-NoDerivs 4.0 Unported License. 